ISSN 1678-3921

Journal homepage: www.embrapa.br/pab

For manuscript submission and journal contents, access: www.scielo.br/pab

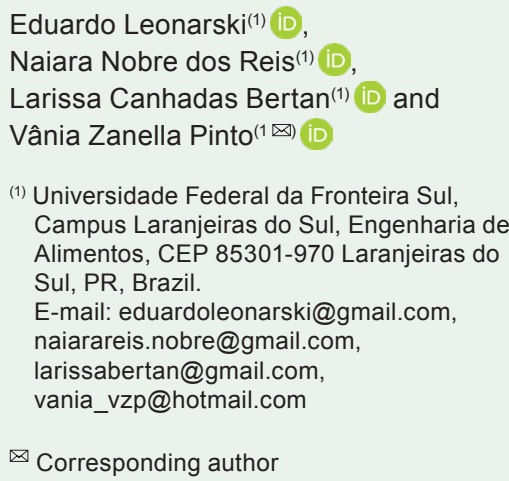

\section{Optimization and sensorial evaluation of guabiroba jam with prebiotic}

\begin{abstract}
The objective of this work was to optimize formulations of guabiroba (Campomanesia xanthocarpa) jam by central composite design $(\mathrm{CCD})$, to evaluate the addition of pectin (P), citric acid (CA), and fructooligosaccharides (FOS). The responses were $\mathrm{pH}$, titratable acidity, and hardness. The CCD showed that CA and FOS were meaningful for titratable acidity, while $\mathrm{P}$ was meaningful for jam hardness. The optimized formulations were $\mathrm{F} 2(0 \% \mathrm{FOS}, 0.5 \% \mathrm{P}$, and $1.5 \% \mathrm{CA}), \mathrm{F} 6(15 \% \mathrm{FOS}, 0.5 \% \mathrm{P}$, and $1.5 \%$ $\mathrm{CA})$, and $\mathrm{F} 9(7.5 \% \mathrm{FOS}, 1 \% \mathrm{P}$, and $1 \% \mathrm{CA})$, which were subjected to chemical composition and sensory analyses. No differences were observed between jam samples for ashes, protein, and lipids. Guabiroba jams showed at least $35 \%$ of the original bioactive compounds (carotenoids, ascorbic acid, and phenolic compounds) from fruit, even after the thermal processing. Formulation F9 containing $7.5 \%$ FOS shows the best taste, overall impression, and purchase intention.
\end{abstract}

Index terms: Campomanesia xanthocarpa, central composite design, fructooligosaccharides, native fruit.

\section{Otimização e avaliação sensorial de geleia de guabiroba com prebiótico}

Resumo - O objetivo deste trabalho foi otimizar formulações de geleia de guabiroba (Campomanesia xanthocarpa), com uso de um delineamento composto central (CCD), para avaliar a adição de pectina (P), ácido cítrico (AC) e fruto-oligossacarídeos (FOS). As respostas foram $\mathrm{pH}$, acidez titulável e dureza. $\mathrm{O} C \mathrm{CD}$ mostrou que $\mathrm{AC}$ e $\mathrm{FOS}$ foram significativos quanto à acidez, e $\mathrm{P}$ foi significativo quanto à dureza da geleia. As formulações otimizadas foram F2 (0\% FOS, $0.5 \%$ P e $1.5 \%$ AC), F6 (15\% FOS, $0.5 \%$ P e $1.5 \% \mathrm{AC})$ e $\mathrm{F} 9(7.5 \% \mathrm{FOS}, 1 \% \mathrm{P}$ e $1 \% \mathrm{AC})$, as quais foram submetidas às análises de composição química e sensoriais. Não se observaram diferenças entre as amostras de geleia quanto a cinzas, proteínas e lipídios. A geleia de guabiroba apresentou no mínimo $35 \%$ dos compostos bioativos (carotenoides, ácido ascórbico e compostos fenólicos) originais dos frutos, mesmo após o processamento térmico. A formulação F9 com 7,5\% de FOS é a que apresenta os melhores parâmetros de sabor, impressão geral e intenção de compra.

Termos para indexação: Campomanesia xanthocarpa, delineamento composto central, fruto-oligossacarídeos, frutas nativas.

\section{Introduction}

Campomanesia xanthocarpa Berg is a native plant from the Myrtaceae family, popularly known as guabiroba or guavirova. It is distributed in Southern Brazil which shows great richness in wild fruits (Pereira et al., 
2012). Guabiroba fruit are consumed in natura by local populations and is underutilized for industrialization (Santos et al., 2013).

Guabiroba fruit can be used to produce homemade jams and jellies, since it contains pectic components required to make these products (Pereira et al., 2012; Santos et al., 2013). Besides their nutritional value, native fruits can be processed, which is a viable alternative to add value to and diversify regional products, as well as increase the income of small farmers. Guabiroba marmalade showed considerable contents of vitamin C (97.39-123.39 mg $100 \mathrm{~g}^{-1}$ ), phenolic compounds (322.09-728.48 $\mathrm{mg} 100 \mathrm{~g} \mathrm{~g}^{-1}$, and carotenoids $(74.81 \pm 2.03-87.66 \pm 2.53$, and a positive correlation was described between these compounds and antioxidant activities (Santos et al., 2013).

In addition to bioactive compounds naturally present in fruits and plants, foods containing prebiotic ingredients are known to be beneficial to health, and their consumption is widely recommended. Most scientific data on prebiotic effects are related to fructans, fructo-oligosaccharidess, and inulin (Oku \& Nakamura, 2017), which are considered to have a functional effect as reported by Agência Nacional de Vigilância Sanitária (Anvisa, 2016), and have been commercially available in Brazil and other countries for many years. Fructo-oligosaccharides are chemically composed of chains of fructose units by glycosidic linkages $\beta$ (2-1) into a glucose terminal molecule (Oku \& Nakamura, 2017). These prebiotics are selectively fermented by some Bifidobacteria. Their fermentation results in short-chain fatty acids such as acetate, propionate, and butyrate that are recognized for having mechanistic links to health outcomes (Oku \& Nakamura, 2017).

Some studies have reported the use of fructooligosaccharides as prebiotic ingredients in products from сириас̧u and açaí nectar (Jesus et al., 2019), and apple jam (Scolforo \& Silva, 2013). Further studies on the preparation of food products with regional fruits and supplementation with fructo-oligosaccharides are needed.

The objective of this work was to optimize guabiroba jam formulations, using a central composite design, with factorial design $2^{3}$, to evaluate the addition of pectin, citric acid, and fructo-oligosaccharides (as prebiotic ingredient).

\section{Materials and Methods}

Fresh guabiroba fruit were collected in the municipality of Laranjeiras do Sul, in the state of Paraná, Brazil, at approximately $840 \mathrm{~m}$ altitude. After sanitization with sodium hypochlorite (200 ppm) for 15 min, fully ripe fruit were mechanically pulped, using a $0.8 \mathrm{~mm}$ sieve (DMJI-05, Hauber Macanuda, Joinville, SC, Brazil). The jam ingredients were fructo-oligosaccharides (FOS) (Metachem, São Paulo, SP, Brazil), commercial crystal sugar (sucrose) (Usina Alto Alegre, Junqueira, PR, Brazil), anhydrous citric acid p.a. 99.5\% (Dinâmica, Barueri, SP, Brazil), and citrus pectin 95\% (Dinâmica, Barueri, SP, Brazil).

The concentrations of pectin (P), citric acid (CA) and fructo-oligosaccharides (FOS) were set by preliminary studies and, then, a central composite design (CCD) $2^{3}$ with three central point replicates was used to determine the formulation tests (Table 1). Eleven trials were processed by the design arrangement, whose encoded and decoded levels are described (Table 2). The Brazilian legislation on functional foods recommends 5 $\mathrm{g}$ as minimum, and $30 \mathrm{~g}$ as maximum FOS content, in the daily consumption of products ready for consumption (Anvisa, 2016). The relationship between the response and the input is given by the equation

$Y=x_{1} A ; x_{2} B+x_{3} C ; x_{12} A B+x_{13} B C \ldots ; x_{n}+\varepsilon$,

in which $\mathrm{Y}$ is the response; $\mathrm{x}_{1}, \mathrm{x}_{2}, \ldots, \mathrm{x}_{\mathrm{n}}$ is the estimated coefficient on the response surface; $\mathrm{A}, \mathrm{B}$, and $\mathrm{C}$ are the encoded variables (FOS, $\mathrm{P}, \mathrm{CA}$ ); and $\varepsilon$ is the pure error. The mathematical model equations and the responsesurface figures generated by these equations were used to show the significant results.

Guabiroba pulp and half of the total sucrose and FOS $\left(\frac{1}{2}\right)$ were cooked in constant stirring, reaching soluble solids until $42{ }^{\circ}$ Brix (Batista et al., 2020) that was measured using a digital refractometer $\mathrm{HI}$

Table 1. Concentration of sucrose/fructo-oligosaccharides (S/FOS), pectin, and citric acid used to produce guabiroba (Campomanesia xanthocarpa) jams.

\begin{tabular}{lccc}
\hline Independent & \multicolumn{3}{c}{ Level } \\
\cline { 2 - 4 } variable & -1 & 0 & 1 \\
\hline S/FOS (\%) & $50 / 0$ & $42.5 / 7.5$ & $35 / 15$ \\
Citric acid (\%) & 0.5 & 1.0 & 1.5 \\
Pectin (\%) & 0.5 & 1.0 & 1.5 \\
\hline
\end{tabular}


96801 (Hanna Instruments, Nusfalau, Transylvania, Romania). Then, the remainder sucrose and FOS $\left(\frac{2}{2}\right)$, $\mathrm{P}$, and CA were added, while the jam was kept under constant stirring until all ingredients were completely solubilized. The soluble solids were measured again, according to Batista et al. (2020), and ranged between $62-65^{\circ}$ Brix.

The samples were stored in sealed glass containers at $6 \pm 2{ }^{\circ} \mathrm{C}$ until their use. The yielded guabiroba jam was calculated by the ratio of the final mass and the initial mass of the ingredients, and the results were expressed in percent.

The $\mathrm{pH}$ of the samples was determined directly by a pHmeter HI221 (Hanna Instruments, Nusfalau, Transylvania, Romania), using $10 \mathrm{~g}$ jam in $100 \mathrm{~mL}$ distilled water. Titratable acidity (TA) was determined using the same jam suspension $(10 \mathrm{~g}$ jam in $100 \mathrm{~mL}$ distilled water) by $0.1 \mathrm{~mol} \mathrm{~L}^{-1} \mathrm{NaOH}$ titration until $\mathrm{pH}$ 8.2 was reached. The titratable acidity as expressed ( $\mathrm{g}$ citric acid $100 \mathrm{~g}^{-1}$ of the sample), according to Horwitz (2005).

Texture profile analysis (TPA) was performed using a texturometer (Stable Micro Systems, TA -XT2i, Goldaming, England), with a cylindrical probe (P/0.5R). The parameter evaluated was hardness $(\mathrm{H})$, using $5.0 \mathrm{~s}$ pre-test velocity, $2.0 \mathrm{~s}$ test speed, $2.0 \mathrm{~s}$ post-test speed, and $10 \mathrm{~mm}$ initial distance, at $25^{\circ} \mathrm{C}$ room temperature.

Only the samples selected by the CCRD optimization were deeply analyzed, as follows: moisture content, ashes, crude protein, total lipids, total carbohydrates, reducing sugars, water activity, soluble solids, total carotenoids, ascorbic acid, total phenolic compounds, color, and sensory analyses.
The moisture content was determined in an oven with air circulation at $105^{\circ} \mathrm{C}$, until constant mass was reached; the ash content was determined by the muffle incineration at $550^{\circ} \mathrm{C}$; crude protein content was determined by the Kjeldahl method with conversion factor 6.25; and the total lipid content was determined by cold extraction (Horwitz, 2005). Total carbohydrates were calculated by the difference between moisture content, ash, crude protein, and lipids, and the content of reducing sugars, in glucose, was determined using Fehling's A and B solutions (Horwitz, 2005).

Water activity (Aw) was measured at $25^{\circ} \mathrm{C}$ by Awmeter CH8863 (Novasina AG, Lachen, Switzerland), and the soluble solids content ( ${ }^{\circ}$ Brix), by a digital refractometer HI 96801 (Hanna Instruments, Nusfalau, Transylvania, Romania). Total carotenoids and ascorbic acid were determined by titration as described by Horwitz (2005), and the total phenolic compounds were determined as described by Kwiatkowski et al. (2010).

The instrumental color analysis was performed using the CIELAB color system with direct colorimeter reading CR400 (Konica Minolta, Tokyo, Japan), and the parameters $\mathrm{L}^{*}$ (lightness), a* (red-green color contribution), and $b^{*}$ (yellow-blue color contribution) were determined. Analyses were performed also for chroma $\left(\mathrm{c}^{*}\right)$, which corresponds to the saturation or intensity of the color, and hue angle $\left(\mathrm{h}^{\circ}\right)$, expressed in degrees in which the $0^{\circ}$ angle shows pure red, $90^{\circ}$ pure yellow, $180^{\circ}$ pure green and $270^{\circ}$ pure blue.

The sensory analyses of the optimized guabiroba jams were carried out after the approval by the Research Ethics Committee of the Universidade Federal da Fronteira Sul (UFFS CAAE \# 78486117.0.0000.5564).

Table 2. Central composite rotational design $2^{3}$ factorial, with coded and real values of independent variables sucrose/ fructo-oligosaccharides (S/FOS), pectin (P), and citric acid (CA).

\begin{tabular}{|c|c|c|c|c|c|c|}
\hline \multirow[t]{2}{*}{ Run } & \multicolumn{3}{|c|}{ Coded } & \multicolumn{3}{|c|}{ Real (\%) } \\
\hline & $\mathrm{X}_{1}$ & $\mathrm{X}_{2}$ & $\mathrm{X}_{3}$ & FOS & $\mathrm{P}$ & $\mathrm{CA}$ \\
\hline F1 & -1 & -1 & -1 & $50 / 0$ & 0.5 & 0.5 \\
\hline F2 & -1 & -1 & +1 & $50 / 0$ & 0.5 & 1.5 \\
\hline F3 & -1 & +1 & -1 & $50 / 0$ & 1.5 & 0.5 \\
\hline F4 & -1 & +1 & +1 & $50 / 0$ & 1.5 & 1.5 \\
\hline F5 & +1 & -1 & -1 & $35 / 15$ & 0.5 & 0.5 \\
\hline F6 & +1 & -1 & +1 & $35 / 15$ & 0.5 & 1.5 \\
\hline F7 & +1 & +1 & -1 & $35 / 15$ & 1.5 & 0.5 \\
\hline F8 & +1 & +1 & +1 & $35 / 15$ & 1.5 & 1.5 \\
\hline F9 & 0 & 0 & 0 & $42.5 / 7.5$ & 1.0 & 1.0 \\
\hline F10 & 0 & 0 & 0 & $42.5 / 7.5$ & 1.0 & 1.0 \\
\hline F11 & 0 & 0 & 0 & $42.5 / 7.5$ & 1.0 & 1.0 \\
\hline
\end{tabular}


The evaluation was carried out by a panel composed by 98 untrained persons (40 men and 58 women), whose ages ranged between 18 and 45 years, who were students and staff members of UFFS. The sensory evaluation - for texture, color, taste, and odor - was carried out using a nine-point hedonic scale, in which 9 represented "liked extremely", and 1 "disliked extremely". Another five-point hedonic scale was used for purchase intent, in which 5 represented "definitely would buy", and 1 represented "definitely would not buy". The optimized guabiroba jam samples were presented in individual cabins, as well as in an anonymous way by a 3-number code.

In order to validate the CCRD model, the analysis of variance was used, at 5\% probability, and each individual variable was subjected to the Student's t-test. The whole model was checked by the F-test, while the regression coefficient $\left(\mathrm{R}^{2}\right)$ was used to check the adjustment of the model to the experimental data. The optimized trials were subjected to the analysis of variance and to the Tukey's test, at 5\% probability for mean comparisons. The statistical analysis was set by Statistica 10.0 (Statsoft, v. 2010).

\section{Results and discussion}

The guabiroba jam yield was over $75.02 \%$ for all experimental runs; the highest yield was $84.08 \%$ for sample F6, and the lowest one was for sample F11 (75.02\%). Scolforo \& Silva (2013) reported a yield ranging from 58.45 to $64.47 \%$ of apple jam with FOS supplementation. The difference in the values of jam yields can be attributed to the addition of FOS, as its dissolution is slower than that of sucrose. However, this difference was not significant according to the model.

The CA was the most important variable for $\mathrm{pH}$ (linear effect), followed by FOS (quadratic effect) $(\mathrm{p}<0.05)$. The model is described by Equation 1, when $\mathrm{P}$ was fixed at $1 \%$. It was validated by the analysis of variation, and shows a high-correlation coefficient $\left(\mathrm{R}^{2}=0.997\right)$ and good performance of the F-test for regression, if $\mathrm{F}_{\text {calc }}<\mathrm{F}_{\text {tab }}$ is significant.

$\mathrm{pH}=3.7175+0.0369 \times \mathrm{FOS}-0.0024 \times \mathrm{FOS}^{2}-$ $0.5933 \times \mathrm{CA}-0.0017 \times 1 \times \mathrm{FOS}+0.0009 \times \mathrm{FOS} \times \mathrm{CA}+$ $0.0550 \times 1 \times \mathrm{CA}$
The surface response of the model described by Equation 1 indicates that the reduction of citric acid concentration promoted an increase of the $\mathrm{pH}$ (Figure $1 \mathrm{~A}$ ). The maximum $\mathrm{pH}$ was around 3.4, when the citric acid concentration was low $(0.5 \%)$, and the lowest $\mathrm{pH}$ of the jams was 2.83, with FOS ranging between 0 and $15 \%$, at $1.5 \%$ citric acid.

The surface response and Equation 2 describe the predictive model for $\mathrm{pH}$, when the FOS concentration was set at $7.5 \%$ (Figure $1 \mathrm{~B}$ ). This effect was similar when $\mathrm{P}$ was fixed at $1 \%$, suggesting that the citric acid concentration influences $\mathrm{pH}$. The pectin gel formation occurs only at $\mathrm{pH}$ around 2.8-3.5. When $\mathrm{pH}$ is over 3.4, gelation does not occur. When $\mathrm{pH}$ is lower than 2.7, syneresis can happen. All guabiroba jam formulations had $\mathrm{pH}$ close to 3.0 and, consequently, good gel formation, without syneresis development (Torrezan, 1998).

$$
\begin{aligned}
& \mathrm{pH}=3.7175-0.0733 \times \mathrm{P}-0.5933 \times \mathrm{CA}-0.0017 \times 7.5 \times \mathrm{P} \\
& +0.0009 \times 7.5 \times \mathrm{CA}+0.0550 \times \mathrm{P} \times \mathrm{CA}
\end{aligned}
$$

CA was the most important variable for titratable acidity (linear effect), while the other variables were not significant $(\mathrm{p}>0.05)$, as described in Equation 3 (pectin was set at $1 \%$ ), and the model was validated by the analysis of variance. It shows a high-correlation coefficient $\left(\mathrm{R}^{2}=0.994\right)$ and a good performance of the F-test $\left(\mathrm{F}_{\text {calc }}<\mathrm{F}_{\text {tab }}\right)$.

$$
\begin{aligned}
& \mathrm{TA}=0.1878+0.0084 \times \mathrm{FOS}-0.0002 \times \mathrm{FOS}^{2}+ \\
& 1.3073 \times \mathrm{CA}-0.0052 \times \mathrm{FOS} \times \mathrm{CA}-0.0034 \times 1 \times \mathrm{FOS}- \\
& 0.2192 \times 1 \times \mathrm{CA}
\end{aligned}
$$

The surface response from Equation 3 indicates an increase of TA, with the increase of citric acid concentration (Figure $2 \mathrm{~A}$ ), in which the jam minimum titratable acidity was $0.9 \mathrm{~g}$ citric acid $100 \mathrm{~g}^{-1}$, at FOS range between 0 and $15 \%$, and $0.5 \%$ CA. The FOS concentration did not change the titratable acidity of the jams, only the citric acid concentration added to the formulations.

The FOS ranges were not significant for the titratable acidity model, $\mathrm{P}$ was not significant either $(\mathrm{p}>0.05)$. The response surface (FOS set at 7.5) showed similar behavior when $\mathrm{P}$ was fixed (Figure $2 \mathrm{~B}$ ), and Equation 4 represents the statistically validated mathematical model. 
A

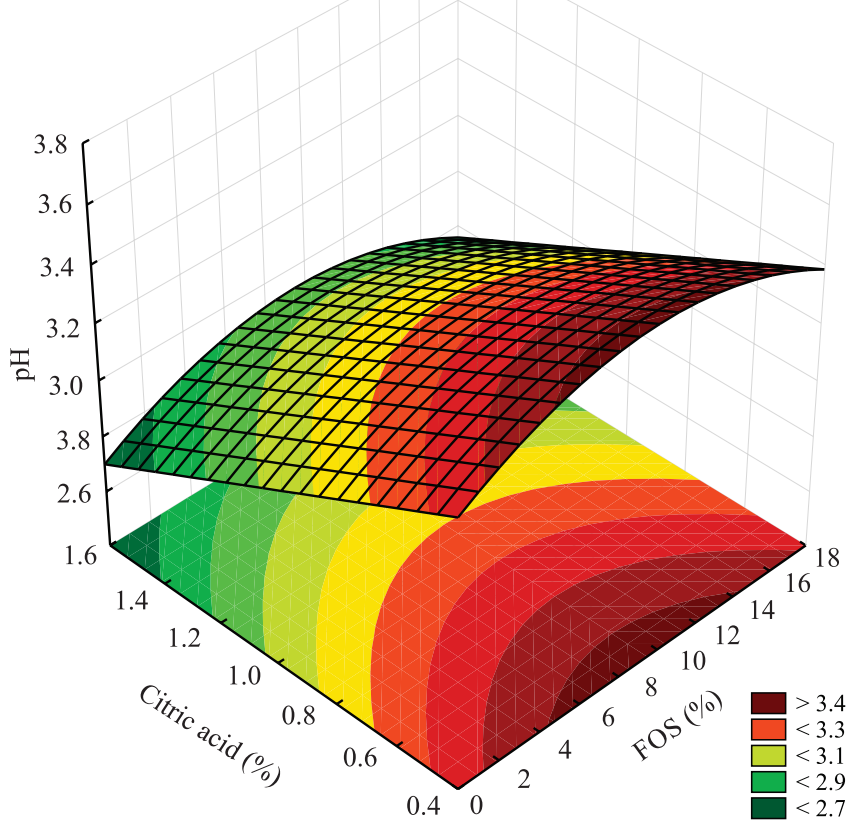

B

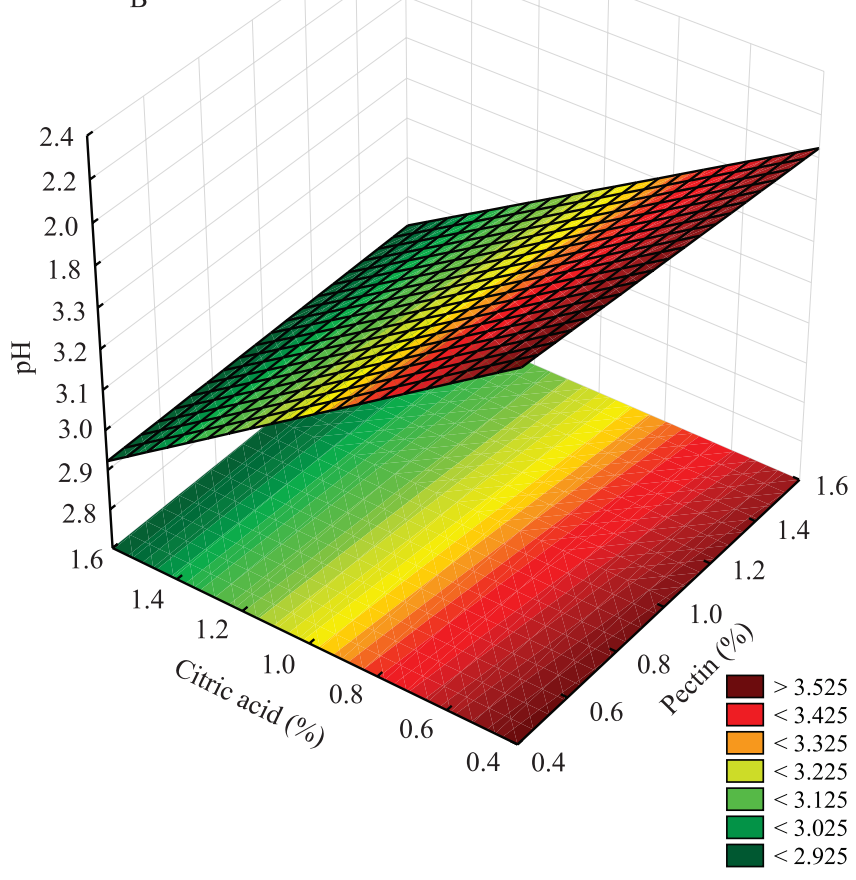

Figure 1. $\mathrm{pH}$ response surfaces of guabiroba (Campomanesia xanthocarpa) jams: A, as a function of fructo-oligosaccharides (FOS) and citric acid concentrations, setting pectin $(1 \%)$; $\mathrm{B}$, as a function of pectin and citric acid concentration, setting FOS (7.5\%).

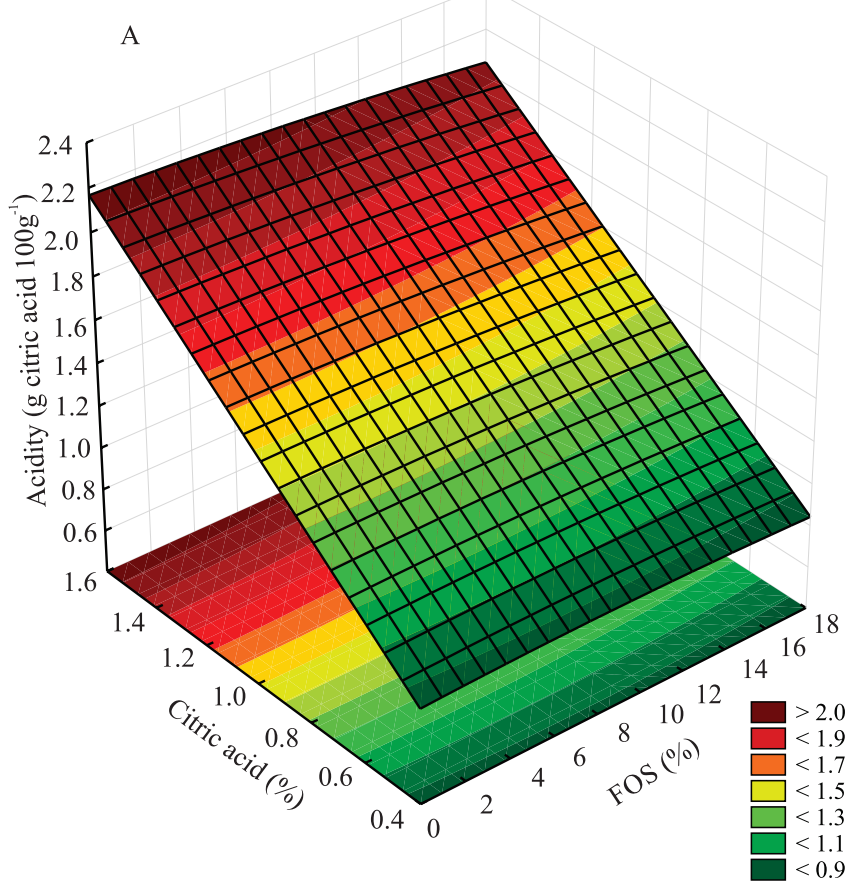

B

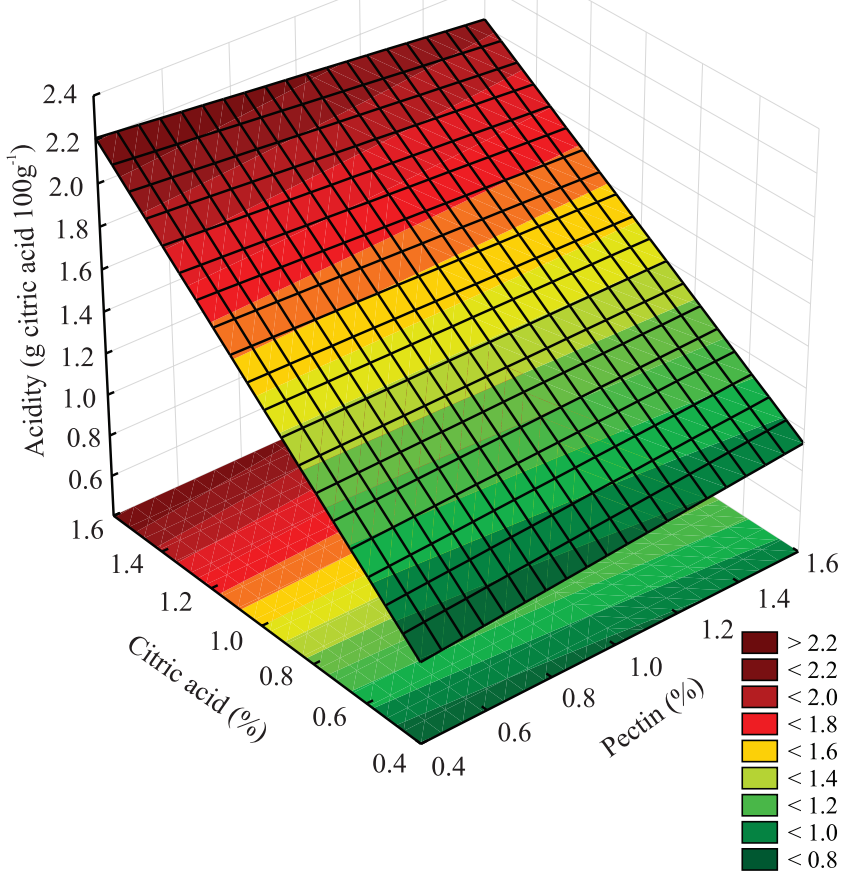

Figure 2. Titratable acidity response surface of guabiroba (Campomanesia xanthocarpa) jams: A, as a function of fructo-oligosaccharides (FOS) and citric acid concentration, setting pectin $(1 \%)$; $\mathrm{B}$, as a function pectin and citric acid concentration, setting FOS (7.5\%). 
$\mathrm{TA}=0.1878+1.307 \times \mathrm{CA}+0.2318 \times \mathrm{P}-$

$0.0052 \times 7.5 \times \mathrm{CA}-0.0033 \times 7.5 \times \mathrm{P}-0.2192 \times \mathrm{CA} \times \mathrm{P}$

Processing causes FOS degradation, since it is degraded when subjected to high temperatures and low pH (Courtin et al., 2009). The protonic activation of the leaving group could be associated with the lower FOS stability at acidic $\mathrm{pH}$. This could also be explained by the fact that when temperature increases, the fragility of the fructose-fructose and fructoseglucose $\mathrm{C}-\mathrm{O}$ osidic bonds involved in the glycosidic linkages in FOS also increases (Wang et al., 2009). For the jam manufacturing process, the temperature was approximately $100^{\circ} \mathrm{C}$ for $5 \mathrm{~min}$ at $\mathrm{pH} 3$ (close to the final product $\mathrm{pH}$ ), FOS degradation is approximately 10\% (Courtin et al., 2009).

Citric acid concentration (1.0 and 1.5\%) is adequate to get good gel formation or guabiroba jam, and $1.5 \%$ citric acid was the best sensorially accepted concentration. However, the natural guabiroba fruit pungency negatively influenced jam without or with the addition of $0.5 \%$ citric acid. This pungency was possibly disguised by the high concentrations of acid (1.0 and 1.5\%). The fact that most individuals lack knowledge about the characteristic flavors of native fruits, such as guabiroba, may have been the main factor of negative interference with the product acceptance (Freitas et al., 2008).

Therefore, the formulations with low-citric acid concentration are not indicated for guabiroba jams with good sensory acceptance. Based on the relationship between titratable acidity and sensory acceptance, only the experimental runs F2, F4, F6, and F8, with $1.5 \%$ citric acid were optimal for jam guabiroba production.

The most important variable $(\mathrm{p}<0.05)$ for hardness was $\mathrm{P}$ (linear effect), while the other variables were not significant, as presented in Equation 5 (citric acid was fixed at $1 \%$ ). The model was validated by the analysis of variance. It shows a high-correlation coefficient $\left(\mathrm{R}^{2}=0.978\right)$, and a good performance of the F-test $\left(\mathrm{F}_{\text {calc }}<\mathrm{F}_{\mathrm{tab}}\right)$.

Hardness $=-34.8986-0.3539 \times \mathrm{FOS}+0.1586 \times \mathrm{FOS}^{2}$ $+79.2085 \times \mathrm{P}-0.0973 \times \mathrm{FOS} \times \mathrm{P}-1.2483 \times 1 \times \mathrm{FOS}-$ $29.6025 \times 1 \times \mathrm{P}$

The predictive model of Equation 5 was plotted by means of response surfaces (Figure $3 \mathrm{~A}$ ), and the pectin concentration increased the jam hardness. The minimum jam hardness was $8 \mathrm{~N}$ with FOS concentration ranging from 0 to $15 \%$, and pectin set at $0.5 \%$. The FOS ratio did not interfere with the hardness. However, FOS interfered with the amount of pectin, since 1.5\% pectin, regardless of FOS concentration, resulted in hardness 10 times higher than the minimum jam hardness (Figure $3 \mathrm{~A}$ ). The natural pectin in guabiroba fruit is not enough to produce good gelation, for which the addition of commercial pectin is necessary (Freitas et al., 2008). The addition of $0.5 \%$ pectin has been described to obtain the characteristic texture of jam, and $1.5 \%$ pectin resulted in very hard guabiroba jam, with a marmalade-like texture. In general, up to $1.0 \%$ commercial pectin is enough to produce a firm jam, considering the natural pectin amount in the fruit (Shinwari \& Rao, 2018). Therefore, in the present study, the addition of $0.5 \%$ of pectin was considered good for gel formation with a semi-solid consistency that is a characteristic of jam.

Equation 6 represents the statistically validated mathematical model for hardness, when the FOS concentration was set at $7.5 \%$. The citric acid range was not significant for the jam hardness $(\mathrm{N})$ model, and only pectin addition was significant $(p<0.05)$.

Hardness $=-34.8986+79.2085 \times \mathrm{P}+25.4620 \times \mathrm{CA}-$ $0.0973 \times 7.5 \times \mathrm{P}-1.2483 \times 7.5 \times \mathrm{CA}-29.6025 \times \mathrm{P} \times \mathrm{CA}$

Equation 6 was plotted by means of response surfaces (Figure $3 \mathrm{~B}$ ) and showed an effect similar to that shown in Figure $3 \mathrm{~A}$. The addition of citric acid $(1.5 \%)$, resulted in the reduction of jam hardness, but this concentration was not enough to promote a significant effect.

After titratable acidity evaluation, only the experimental runs F2, F4, F6, and F8 were suitable for guabiroba jam production, since they showed the highest citric acid concentrations (1.5\%). Among these formulations, F2 and F6 - with $0.5 \%$ pectin - showed a semi-solid consistency that characteristic of these products. Therefore, experimental runs F2 and F6 were considered optimal for guabiroba jam production. The central point F9 was also considered for further characterization.

The F2, F6, and F9 formulations showed similar color, which was homogeneous, coming from the guabiroba pulp. For a global visual aspect, there were no differences between the optimized experimental 
runs and central point, regardless of the difference of pectin, citric acid, and FOS ratios.

The moisture content of the F2 and F6 experimental runs was not different; and F9 showed a higher

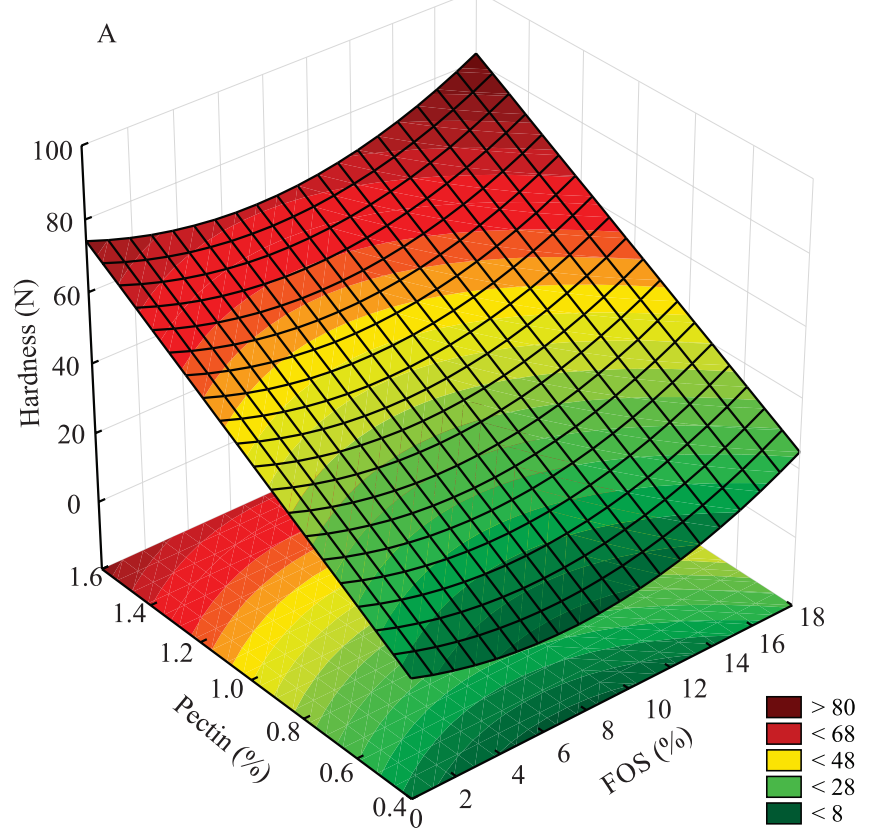

B

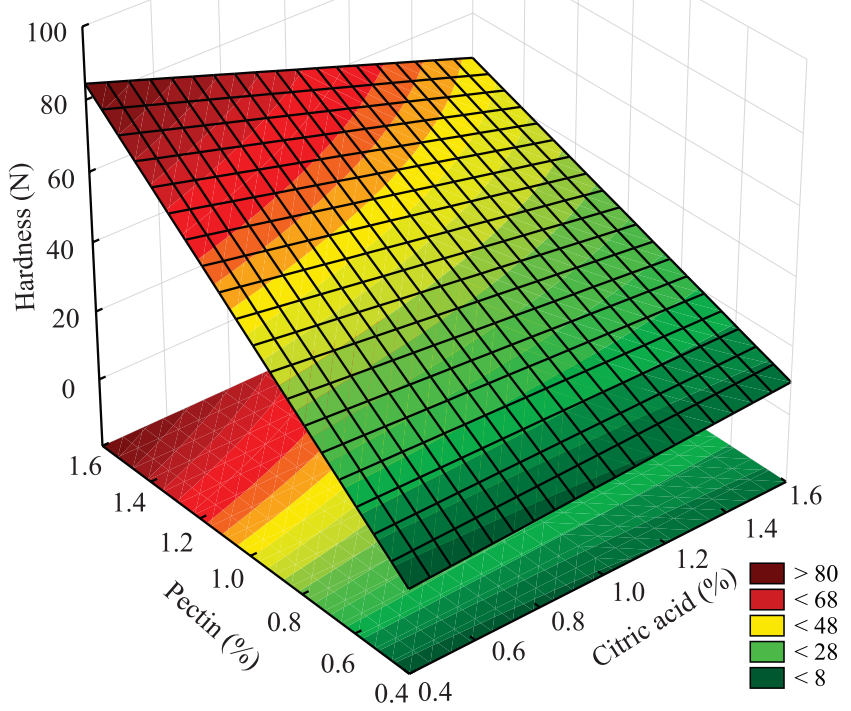

Figure 3. Hardness-response surface of guabiroba (Campomanesia xanthocarpa) jams: A, as a function of fructo-oligosaccharides (FOS) and pectin concentration, setting citric acid (1\%); B, as a function of pectin and citric acid concentration, setting FOS (7.5\%). moisture content than them (Table 3). The jam moisture reduction was due to the total solids increase that resulted from the cooking process and from water evaporation (Rosa et al., 2012). FOS shows OH groups available for binding that can bond with water, reducing the rate of water evaporation, forming a cohesive gel network and, thus, contributing to the difference of moisture between F6 (15\% FOS) and F9 (7.5\% FOS). In addition, the excess of acidity can cause the pectin dehydration and hydrolysis, as well as water release from the gel matrix (Freitas et al., 2008).

The ash content in guabiroba jam did not differ between samples (Table 3), which corroborates the findings by Scolforo \& Silva (2013), who reported 0.27 to $0.28 \%$ ashes form apple jam with FOS. The ash content is related to the type of fruit used in the formulation. The protein content of all jam samples ranged between 0.59 and $0.72 \%$. The lipid content of jam ranged between 0.56 and $0.58 \%$, with no differences from each other.

These behaviors were expected, since none of the added ingredients had high ash, protein, or fat content, as most of them were from the guabiroba pulp, which was used at the same concentration in all formulations.

The content of reducing sugars from F2 (50\% sucrose) and F9 (42.5\% sucrose, and 7.5\% FOS) showed no differences. F6 experimental run, which contained the highest FOS concentration (35\% sucrose and 15\% FOS) resulted in the highest reducing sugars (Table 3). The run with the highest amount of reducing sugars contained the lowest sucrose content and the highest FOS content. The citric acid added may also have formed invert sugar from sucrose; these compounds with more citric acid tend to form hydrogen bridges with pectin, forming the gel (Einhorn-Stoll, 2018). In addition, the highest content of reducing sugars indicates that FOS may have degraded during the cooking process and released reducing sugars.

Caetano et al. (2012) reported 21.69 and 32.55\% reducing sugars in acerola pulp jam with different sugar and pulp ratios, and described that the highest reducing sugar was from pure pulp jam. The high content of reducing sugars indicates that there was some carbohydrate hydrolysis, either natural or added, during the product cooking (Batista et al., 2020). Thus, there is an indication that FOS gave the product a higher percentage of monosaccharides than sucrose, 
resulting in jam with higher concentrations of reducing sugars (Table 3 ).

The jam showed water activity between 0.83 and 0.86 , and did not differ from each other (Table 3). According to Moura et al. (2011), jellies and jams that have water activity equal to or greater than 0.88 , need the addition of preservatives, as these are considered semi-perishable.

Samples F2 and F6, containing $1.5 \%$ citric acid had the same $\mathrm{pH}$, differing from the $\mathrm{F} 9$ sample, which contained $1.0 \%$ citric acid (Table 3 ). Thus, the recommended $\mathrm{pH}$ for jams should be higher than 2.7 (since syneresis may occur) and lower than 3.5, in order to make gel which is not too weak (Torrezan, 1998). The citric acid addition in guabiroba jam formulations was essential for the adequate gel formation and consequent characteristic texture. F2 and F6 experimental runs showed no differences $(p>0.05)$ for titratable acidity, which was low in F9 because of the citric acid concentration (1.0\%). Titratable acidity

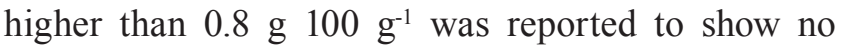
interference with the physicochemical characteristics and positive results in jam subjected to sensory analysis (Yuyama et al., 2008).

The soluble solid contents did not differ between the guabiroba jams, and ranged between 65.2 and $67.4^{\circ}$ Brix. Although the Brazilian legislation indicates soluble solids between $62-65^{\circ}$ Brix, the Codex Alimentarium

Table 3. Physicochemical characteristics of guabiroba (Campomanesia xanthocarpa) jam, in the experimental formulations F2, F6, and F9 ${ }^{(1)}$.

\begin{tabular}{lrrr}
\hline Trait & \multicolumn{3}{c}{ Formulation ${ }^{(2)}$} \\
\cline { 2 - 4 } & \multicolumn{1}{c}{ F2 } & F6 & F9 \\
\hline Water activity & $0.83 \pm 0.00 \mathrm{a}$ & $0.84 \pm 0.00 \mathrm{a}$ & $0.86 \pm 0.01 \mathrm{a}$ \\
$\mathrm{pH}$ & $2.84 \pm 0.01 \mathrm{~b}$ & $2.84 \pm 0.01 \mathrm{~b}$ & $3.24 \pm 0.00 \mathrm{a}$ \\
Titratable acidity $\left(\mathrm{g} 100^{-1} \mathrm{~g}\right)$ & $2.07 \pm 0.03 \mathrm{a}$ & $2.06 \pm 0.02 \mathrm{a}$ & $1.45 \pm 0.01 \mathrm{~b}$ \\
Soluble solids $\left({ }^{\circ}\right.$ Brix) & $66.3 \pm 0.50 \mathrm{a}$ & $67.4 \pm 0.16 \mathrm{a}$ & $65.2 \pm 0.48 \mathrm{a}$ \\
Lightness (L*) & $30.7 \pm 1.15 \mathrm{a}$ & $32.8 \pm 0.42 \mathrm{a}$ & $33.5 \pm 0.48 \mathrm{a}$ \\
Croma (c*) & $16.1 \pm 0.51 \mathrm{a}$ & $18.9 \pm 1.31 \mathrm{a}$ & $19.7 \pm 0.47 \mathrm{a}$ \\
Hue angle $\left({ }^{\circ}\right)$ & $62.7 \pm 0.56 \mathrm{~b}$ & $61.7 \pm 1.40 \mathrm{~b}$ & $66.9 \pm 0.49 \mathrm{a}$ \\
Moisture $(\%)$ & $31.1 \pm 1.39 \mathrm{~b}$ & $32.71 \pm 0.14 \mathrm{~b}$ & $36.12 \pm 0.21 \mathrm{a}$ \\
Ashes $(\%)$ & $0.45 \pm 0.06 \mathrm{a}$ & $0.43 \pm 0.09 \mathrm{a}$ & $0.35 \pm 0.11 \mathrm{a}$ \\
Protein $(\%)$ & $0.72 \pm 0.03 \mathrm{a}$ & $0.65 \pm 0.01 \mathrm{~b}$ & $0.59 \pm 0.01 \mathrm{~b}$ \\
Lipids $(\%)$ & $0.58 \pm 0.10 \mathrm{a}$ & $0.57 \pm 0.05 \mathrm{a}$ & $0.56 \pm 0.09 \mathrm{a}$ \\
Total carbohydrates $(\%)$ & $67.15 \pm 1.37 \mathrm{a}$ & $65.64 \pm 0.25 \mathrm{a}$ & $62.38 \pm 0.19 \mathrm{~b}$ \\
SRG $(\%)$ & $26.68 \pm 0.40 \mathrm{~b}$ & $30.80 \pm 0.99 \mathrm{a}$ & $27.73 \pm 0.60 \mathrm{~b}$ \\
\hline
\end{tabular}

(1)Means followed by equal letters do not differ, by the Tukey's test, at $5 \%$ probability. ${ }^{(2)} \mathrm{F} 2,0 \% \mathrm{FOS}, 1.5 \%$ citric acid, and $0.5 \%$ pectin; $\mathrm{F} 6,15 \%$ FOS, $1.5 \%$ citric acid, and $0.5 \%$ pectin; and $\mathrm{F} 9,7.5 \% \mathrm{FOS}, 1.0 \%$ citric acid, and $1.0 \%$ pectin. SRG, reducing sugars in glucose.
(Rahman et al., 2018), Malaysia legislation - Food Act and Regulation (Anuar \& Salleh, 2019), and the Indonesian National Standard (Kurniawati et al., 2019) indicate a content higher than $65^{\circ}$ Brix. Soluble solids should be around $67.5^{\circ}$ Brix for jam preparation because, if higher, there would be formation of sugar crystals and, if lower, it would result in very liquid jam (Torrezan, 1998).

The guabiroba color showed no differences for $\mathrm{L}^{*}$ and $\mathrm{c}^{*}$. The $\mathrm{L}^{*}$ ranged from 30.7 to 33.5 , as well as $\mathrm{c}^{*}$ ranged from 16.1 to 19.7 in the three experimental runs (Table 3). Santos et al. (2013) verified L* for guabiroba jams between 40.96 and 43.45 and, to our knowledge, no $\mathrm{c}^{*}$ from this kind of product was reported.

The F9 experimental run showed the highest-hue angle. F2, F6, and F9 showed 62.7, 61.7, and 66.9 hue angles, respectively, indicating a mixture of red and yellow, which resulted in an orange color characteristic of guabiroba fruit. F9 showed a more yellowish color than the other samples.

The guabiroba pulp had $116.55 \mu \mathrm{g} \beta$-carotene $\mathrm{g}^{-1}$ of total carotenoids (Table 4). These compounds have shown significant preventive and therapeutic benefits against age-related eye diseases (Bungau et al., 2019), and protective effects of the carotenoids on nonalcoholic fatty liver disease (Lee et al., 2019). The consumption of carotenes has also been associated with a decreased risk for cardiovascular disease, cancer, age-related macular degeneration, and photosensitivity associated with UV exposure (Cooperstone \& Schwartz, 2016).

The predominant carotenoids in guabiroba fruit are $42 \% \quad \beta$-carotene, $32 \% \quad \beta$-cryptoxanthin, and 19.12\% $\alpha$-carotene (Santos et al., 2013). Among them, $\beta$-carotene is the most abundant and the most important for food, followed by the $\alpha$-carotene and $\beta$-cryptoxanthin, both having half the pro-vitamin A activity when compared to $\beta$-carotene. The carotenoid content in fruits and vegetables depends on genetic variability, maturation stage, post-harvest storage, processing, and preparation, among other factors (Nanta et al., 2020; Ngamwonglumlert et al., 2020).

Total carotenoids from guabiroba jam ranged from 43.76 to $51.31 \mu \mathrm{g} \beta$-carotene $\mathrm{g}^{-1}$, and F6 and F9 differed from each other $(\mathrm{p}<0.05)$. The guabiroba jams preparation promoted $58.88,55.98$, and $62.45 \%$ reduction of the carotenoid contents for the F2, F6, and F9 experimental runs, respectively, in comparison to the fruit pulp (Table 4). As there was no time control during the cooking process, since the sucrose and FOS 
dissolution were distinct, these compounds may have suffered degradation, depending on the cooking time of each formulation.

Some losses of total carotenoids were reported by Rutz et al. (2012) during the preparation of physalis pulp jams with $64.4 \%$ of degradation, when compared to its counterpart. The decrease of total carotenoid content is generally high in the production of jams, in comparison to the respective fruit pulp. The degradation of this compound is caused by high temperatures, exposure to light and oxygen, presence of moisture, extreme $\mathrm{pHs,}$ oxidizing and reducing agents, presence of metallic ions, and the type of process to which the food is subjected (Shinwari \& Rao, 2018). Therefore, organic acids, such as ascorbic acid, can promote some carotene protection (Maciel et al., 2009), and the formulations with the highest carotenoid concentration were the same ones containing the highest ascorbic acid amount (Table 4).

Although the pulp of guabiroba is rich in ascorbic acid, with $0.566 \mathrm{~g}$ ascorbic acid $100 \mathrm{~g}^{-1}$ pulp, the jams did not differ one from another for this organic acid (Table 4). However, there was high vitamin C loss during cooking than that from the pulp, with $63.96,62.54$, and $64.66 \%$ for F2, F6, and F9 experimental formulations, respectively. These results corroborate the study by Santos et al. (2013), who reported 69.86-74.28\% loss for guava marmalade. The main factors that affect the vitamin content in fruits are: stage of maturation, species, genetic variations, storage, processing, and post-harvest management (Pereira et al., 2012).

According to the Brazilian law, the recommended daily intake (DIR) of vitamin C is $45 \mu \mathrm{g}$ per day (Anvisa, 2005), then, the high content of vitamin $C$ in jams indicated that they are a good source of it, and that they can be an important food to meet the daily requirements of this vitamin. Vitamin $\mathrm{C}$ is known for its potential to neutralize oxidative damage and, consequently, it acts in the beginning of the progression of several chronic and acute diseases (Grosso et al., 2013).

The total phenolic compound content present in guabiroba pulp was $752.3 \mathrm{mg}$ GAE $100 \mathrm{~g}^{-1}$ pulp, which is superior to this parameter in physalis (146.7 mg GAE $100 \mathrm{~g}^{-1}$ ) (Rutz et al., 2012) and in some fruits from Brazilian Cerrado, such as cashew, guapeva, cagaita, cambucá, jaracatiá, mama-cadela, pera-docerrado and pitanga-do-cerrado (90-327 mg GAE $100 \mathrm{~g}^{-1}$ pulp) (Rocha et al., 2011). The experimental runs showed 466.76-511.96 mg GAE $100 \mathrm{~g} \mathrm{~g}^{-1} \mathrm{jam}$, and F9 showed the lowest phenolic content. In comparison to guabiroba pulp, the jams had a decrease of total phenolic compound content of 32.68, 31.95, and $37.96 \%$, for F2, F6, and F9, respectively.

Some authors reported a reduction of phenolic compound contents after jellies and jams production, $40.36-50.18 \%$ for cherry jams, $42.61-56.82 \%$ for plum jellies, as well as $16.19 \%$ for physalis jams (Rutz et al., 2012), and an increase in cubiu jams ranging from 20.34 to $32.39 \%$ (Yuyama et al., 2008). Fruits subjected to thermal processing may have or not a decrease of the total phenolic compound contents in the final products (Shinwari \& Rao, 2018).

The guabiroba jams showed no differences for the appreciation of color, texture, and aroma, which may be classified as liked moderately (mean score $=7$ ) (Table 5)

The taste of F9 had a higher average score than 7 (liked moderately) and differed from the other samples $(\mathrm{p}>0.05)$, which had a mean score around 6 (liked mildly) without differences (Table 5). Freitas et al. (2008) suggested that the slightly bitter taste and pungency, which is natural of guabiroba fruit, may have negatively influenced the acceptance of jams with no citric acid or with the addition of $0.5 \%$ acid. Besides, the sensory analysis showed that $1.5 \%$ citric acid resulted in a very acidic jam, changing the sweet-

Table 4. Total carotenoids, ascorbic acid, and phenolic compounds from guabiroba (Campomanesia xanthocarpa) fruit pulp and jams, in the experimental formulations F2, F6, and F9 ${ }^{(1)}$.

\begin{tabular}{lcccc}
\hline Component & Guabiroba pulp & \multicolumn{2}{c}{ Formulation ${ }^{(2)}$} \\
\cline { 3 - 5 } & & F2 & F6 & F9 \\
\hline Total carotenoids $\left(\mu \mathrm{g} \beta\right.$-carotene $\left.\mathrm{g}^{-1}\right)$ & $116.55 \pm 1.33 \mathrm{a}$ & $47.93 \pm 2.33 \mathrm{bc}$ & $51.31 \pm 2.61 \mathrm{~b}$ & $43.76 \pm 1.90 \mathrm{c}$ \\
Ascorbic acid $\left(\mathrm{mg}\right.$ ascorbic acid $\left.100 \mathrm{~g}^{-1}\right)$ & $565.73 \pm 7.80 \mathrm{a}$ & $203.97 \pm 10 \mathrm{~b}$ & $212.65 \pm 12 \mathrm{~b}$ & $200.37 \pm 5.49 \mathrm{~b}$ \\
Total phenolic compound $\left(\mathrm{mg} \mathrm{GAE} 100 \mathrm{~g}^{-1}\right)^{(1)}$ & $752.3 \pm 1.92 \mathrm{a}$ & $506.45 \pm 4.57 \mathrm{~b}$ & $511.96 \pm 2.1 \mathrm{~b}$ & $466.76 \pm 3.95 \mathrm{c}$ \\
\hline
\end{tabular}

${ }^{(1)}$ Means followed by equal letters do not differ, by the Tukey's test, at 5\% probability. ${ }^{(2)} \mathrm{F} 2,0 \% \mathrm{FOS}, 1.5 \%$ citric acid, and $0.5 \%$ pectin; F6, $15 \%$ FOS, $1.5 \%$ citric acid, and $0.5 \%$ pectin; and $\mathrm{F} 9,7.5 \% \mathrm{FOS}, 1.0 \%$ citric acid, and $1.0 \%$ pectin. GAE, gallic acid equivalent. 
Table 5. Sensory attributes from the experimental runs F2, F6, and F9 guabiroba (Campomanesia xanthocarpa) jams, in the experimental formulations F2, F6, and F9 ${ }^{(1)}$.

\begin{tabular}{|c|c|c|c|c|c|c|}
\hline Formulation $^{(2)}$ & Color & Flavor & Texture & Aroma & Overall impression & Purchase intention \\
\hline F2 & $7.38 \pm 1.29 \mathrm{a}$ & $6.29 \pm 1.88 \mathrm{~b}$ & $7.24 \pm 1.29 \mathrm{a}$ & $6.83 \pm 1.59 \mathrm{a}$ & $6.93 \pm 1.61 \mathrm{ab}$ & $3.35 \pm 1.12 b$ \\
\hline F6 & $7.36 \pm 1.30 \mathrm{a}$ & $5.93 \pm 2.06 \mathrm{~b}$ & $6.91 \pm 1.47 \mathrm{a}$ & $6.89 \pm 1.63 \mathrm{a}$ & $6.48 \pm 1.91 \mathrm{~b}$ & $2.90 \pm 1.22 \mathrm{c}$ \\
\hline F9 & $7.34 \pm 1.28 \mathrm{a}$ & $7.10 \pm 1.62 \mathrm{a}$ & $7.18 \pm 1.42 \mathrm{a}$ & $7.00 \pm 1.50 \mathrm{a}$ & $7.20 \pm 1.42 \mathrm{a}$ & $3.69 \pm 1.07 \mathrm{a}$ \\
\hline
\end{tabular}

${ }^{(1)}$ Means followed by equal letters do not differ, by the Tukey's test, at $5 \%$ probability. ${ }^{(2)} \mathrm{F} 2,0 \% \mathrm{FOS}, 1.5 \%$ citric acid, and $0.5 \%$ pectin; F6, $15 \%$ FOS, $1.5 \%$ citric acid, and $0.5 \%$ pectin; and $\mathrm{F} 9,7.5 \% \mathrm{FOS}, 1.0 \%$ citric acid, and $1.0 \%$ pectin.

acid balance and, consequently, lower score means than that of the jams with $1 \%$ citric acid.

The overall impression of guabiroba jams was higher for F9 (mean score=7.20) and did not differ from F2 (mean score=6.9). The F6 sample had the lowest score (6.5), but it did not differ from F2 (Table 5). The lowest score for F6 can be the result of the FOS concentration, which reduced the sweetness of the jams, due to its lower sweetening power than that of sucrose, enhancing the acid taste, while F2 had only sucrose and the same citric acid concentration. However, the F6 sample obtained a score that graded it as slightly liked for the overall impression.

The mean score 3 indicates that the consumer might buy or perhaps not buy the jam, and the F9 sample was preferred by the evaluators (3.7) (Table 5). Thus, the addition of $1.0 \%$ citric acid was enough to get a good gel formation and did not impair the sensory characteristics of the guabiroba jams. In addition, 7.5\% FOS also did not affect jams, either technologically or sensorially. Thus, the use of prebiotics in guabiroba jams is considered promising for a balanced diet, providing several essential nutrients for a healthy diet, besides being well accepted by the tasters in the sensory analyses.

\section{Conclusions}

1. The addition of fructo-oligosaccharides does not affect $\mathrm{pH}$, titratable acidity, and hardness of guabiroba (Campomanesia xanthocarpa) jams.

2. The optimized guabiroba jams show at least $35 \%$ of the original bioactive compounds (carotenoids, ascorbic acid, and phenolic compounds) from the fruit, even after the thermal processing.

3. The formulation containing $7.5 \%$ fructooligosaccharides shows the best taste, overall impression, and purchase intention.

\section{References}

ANUAR, N.A.; SALLEH, R.M. Development of fruit jam from Averrhoa bilimbi L. Journal of Food Processing and Preservation, v.43, e13904, 2019. DOI: https://doi.org/10.1111/jfpp.13904.

ANVISA. Agência Nacional de Vigilância Sanitária. Alimentos com alegações de propriedades funcionais e ou de saúde. Brasília: ANVISA, 2016. Available at: $<$ http://portal. anvisa.gov.br/ alimentos/alegações>. Accessed on: Sept. 212020.

ANVISA. Agência Nacional de Vigilância Sanitária. ResoluçãoRDC n ${ }^{\circ}$ 269, de 22 de setembro de 2005. [Aprova o Regulamento técnico sobre a Ingestão Diária Recomendada (IDR) de proteína, vitaminas e minerais]. Diário Oficial [da] República Federativa do Brasil, 23 set. 2005. Seçãol, p.372.

BATISTA, R.V.; ROSÁRIO, F.M.; ALVES, V.; FRANCISCO, C.T. dos P.; TORMEN, L.; BERTAN, L.C. Desenvolvimento de iogurte tipo "sundae" sabor jabuticaba (Myrciaria jaboticaba (Vell) Berg) com adição de fibras. Research, Society and Development, v.9, e214996662, 2020. DOI: https://doi.org/10.33448/rsd-v9i9.6662.

BUNGAU, S.; ABDEL-DAIM, M.M.; TIT, D.M.; GHANEM, E.; SATO, S.; MARUYAMA-INOUE, M.; YAMANE, S.; KADONOSONO, K. Health benefits of polyphenols and carotenoids in age-related eye diseases. Oxidative Medicine and Cellular Longevity, v.2019, ID 9783429, 2019. DOI: https://doi.org/10.1155/2019/9783429.

CAETANO, P.K.; DAIUTO, É.R.; VIEITES, R.L. Característica físico-química e sensorial de geleia elaborada com polpa e suco de acerola. Brazilian Journal of Food Technology, v.15, p.191-197, 2012. DOI: https://doi.org/10.1590/s1981-67232012005000011.

COOPERSTONE, J.L.; SCHWARTZ, S.J. Recent insights into health benefits of carotenoids. In: CARLE, R.; SCHWEIGGERT, R.M. (Ed.). Handbook on natural pigments in food and beverages: industrial apllications for improving food color. Amsterdam: Elsevier, 2016. p.473-497. DOI: https://doi.org/10.1016/B978-0-08-100371-8.00020-8.

COURTIN, C.M.; SWENNEN, K.; VERJANS, P.; DELCOUR, J.A. Heat and $\mathrm{pH}$ stability of prebiotic arabinoxylooligosaccharides, xylooligosaccharides and fructooligosaccharides. Food Chemistry, v.112, p.831-837, 2009. DOI: https://doi.org/10.1016/j. foodchem.2008.06.039.

EINHORN-STOLL, U. Pectin-water interactions in foods: from powder to gel. Food Hydrocolloids, v.78, p.109-119, 2018. DOI: https://doi.org/10.1016/j.foodhyd.2017.05.029.

FREITAS, J.B. de; CÂNDIDO, T.L.N.; SILVA, M.R. Geleia de gabiroba: avaliação da aceitabilidade e características físicas e químicas. Pesquisa Agropecuária Tropical, v.38, p.87-94, 2008. 
GROSSO, G.; BEI, R.; MISTRETTA, A.; MARVENTANO, S.; CALABRESE, G.; MASUELLI, L.; GIGANTI, G.; MODESTI, A.; GALVANO, F.; GAZZOLO, D. Effects of vitamin C on health: a review of evidence. Frontiers in Bioscience, v.18, p.1017-1029, 2013. DOI: https://doi.org/10.2741/4160.

HORWITZ, W. (Ed.). Official methods of analysis of AOAC International. $18^{\text {th }}$ ed. Gaithersburg: AOAC International, 2005. Official Methods 900.02, 920.183, 925.45, 942.15, 970.64, 978.04.

JESUS, M.M.A.; FERREIRA, I.M.; SANTOS, L.V. do N.; SILVA, A.M.O.; CAVRALHO, M.G. Fruit nectar obtained from cupuaçu (theobroma grandi-florum) and açaí (euterpe oleracea mart) added with fructo-oligosaccharides : processing and quality evaluation. Demetra: Alimentação, Nutrição \& Saúde, v.14, e33194, 2019. DOI: https://doi.org/10.12957/demetra.2019.33194.

KURNIAWATI, E.C.; HUSAMAH; LATIFA, R.; ZAENAB, S.; PERMANA, T.I.; FAUZI, A. Making Eucheuma cottonii Doty jam with various palm sugar concentrations. Internation Conference on Life Sciences and Technology, v.276, art.012019, 2019. DOI: https://doi.org/10.1088/1755-1315/276/1/012019.

KWIATKOWSKI, A.; FRANÇA, G.; OLIVEIRA, D.M.; ROSA, C.I.L.F.; CLEMENTE, E. Chemical evaluation of pulp and residue pulp of organic blackberry, cv. Tupy. Revista Brasileira de Pesquisa em Alimentos, v.1, p.43-45, 2010. DOI: https://doi.org/10.14685/rebrapa.vli1.9.

LEE, Y.; HU, S.; PARK, Y.-K.; LEE, J.-Y. Health benefits of carotenoids: a role of carotenoids in the prevention of nonalcoholic fatty liver disease. Preventive Nutrition and Food Science, v.24, p.103-113, 2019. DOI: https://doi.org/10.3746/ pnf.2019.24.2.103.

MACIEL, M.I.S.; MELO, E. de A.; LIMA, V.L.A.G. de; SILVA, W.S. da; MARANHÃO, C.M.C.; SOUZA, K.A. de. Características sensoriais e físico-químicas de geleias mistas de manga e acerola. Boletim Centro de Pesquisa de Processamento de Alimentos, v.27, p.247-256, 2009. DOI: https://doi.org/10.5380/ cep.v27i2.22035.

MOURA, S.C.S.R. de; PRATI, P.; VISSOTTO, F.Z.; ORMENESE, R. de C.S.C.; RAFACHO, M. dos S. Color degradation kinetics in low-calorie strawberry and guava jellies. Food Science and Technology, v.31, p.758-764, 2011. DOI: https://doi.org/10.1590/ s0101-20612011000300032.

NANTA, N.; SONGSRI, P.; SURIHARN, B.; LERTRAT, K.; LOMTHAISONG, K.; PATANOTHAI, A. Seasonal variation in lycopene and $\beta$-carotene content in Momordica cochinchinensis (Lour.) Spreng. (Gac fruit) genotypes. Pakistan Journal of Botany, v.52, p.235-241, 2020. DOI: https://doi.org/10.30848/ PJB2020-1(39).

NGAMWONGLUMLERT, L.; DEVAHASTIN, S.; CHIEWCHAN, N.; RAGHAVAN, V. Plant carotenoids evolution during cultivation, postharvest storage, and food processing : a review. Comprehensive Reviews in Food Science and Food Safety, v.19, p.1561-1604, 2020. DOI: https://doi.org/10.1111/15414337.12564.

OKU, T.; NAKAMURA, S. Fructooligosaccharide: metabolism through gut microbiota and prebiotic effect. Food \& Nutrition Journal, v.2, p.1-10, 2017. DOI: https://doi.org/10.29011/25757091.100028 .
PEREIRA, M.C.; STEFFENS, R.S.; JABLONSKI, A.; HERTZ, P.F.; RIOS, A.D.O. Characterization and antioxidant potential of Brazilian fruits from the Myrtaceae family. Journal of Agricultural and Food Chemistry, v.60, p.3061-3067, 2012. DOI: https://doi.org/10.1021/jf205263f.

RAHMAN, T.U.; AMANULLAH; TAHIR, N.; WAHAAB, S.; TAHIR, A.; RAHMAN, A.U.; KHAN, A. Evaluation and preparation of guava jam stored at ambient temperature. Pure and Applied Biology, v.7, p.1064-1073, 2018. DOI: https://doi.org/10.19045/bspab.2018.700125.

ROCHA, W.S.; LOPES, R.M.; SILVA, D.B. da; VIEIRA, R.F.; SILVA, J.P. da; AGOSTINI-COSTA, T. da S. Compostos fenólicos totais e taninos condensados em frutas nativas do cerrado. Revista Brasileira de Fruticultura, v.33, p.1215-1221, 2011. DOI: https://doi.org/10.1590/S0100-29452011000400021.

ROSA, N.C.; TRINTIM, L.T.; CORRÊA, R.C.G.; VIEIRA, A.M.S.; BERGAMASCO, R. Elaboração de geléia de abacaxi com hortelã zero açúcar: processamento, parâmetros físicoquímicos e análise sensorial. Revista Tecnológica, p.83-89, 2012. Edição Especial V Simpósio de Engenharia, Ciência e Tecnologia de Alimentos.

RUTZ, J.K.; VOSS, G.B.; JACQUES, A.C.; PERTUZATTI, P.B.; BARCIA, M.T.; ZAMBIAZI, R.C. Geleia de Physalis peruviana L.: Caracterização bioativa, antioxidante e sensorial. Alimentos e Nutrição, v.23, p.369-375, 2012.

SANTOS, M. da S.; LIMA, J.J. de; PETKOWICZ, C.L. de O.; CANDIDO, L.M.B. Chemical characterization and evaluation of the antioxidant potential of gabiroba jam (Campomanesia xanthocarpa Berg). Acta Scientiarum. Agronomy, v.35, p.73-82, 2013. DOI: https://doi.org/10.4025/actasciagron.v35i1.14389.

SCOLFORO, C.Z.; SILVA, E.M.M. da. Elaboração de geleia de maçã enriquecida com fruto-oligossacarídeo. Alimentos e Nutrição, v.24, p.115-125, 2013.

SHINWARI, K.J.; RAO, P.S. Stability of bioactive compounds in fruit jam and jelly during processing and storage : a review. Trends in Food Science \& Technology, v.75, p.181-193, 2018. DOI: https://doi.org/10.1016/j.tifs.2018.02.002.

STATSOFT, INC. STATISTICA (data analysis software system). version 10. 2010. Available at: $<$ http://www.statsoft.com. br>. Accessed on: Nov. 42020.

TORREZAN, R. Manual para produção de geléias de frutas em escala industrial. Rio de Janeiro: Embrapa-CTAA, 1998. 15p. (EMBRAPA-CTAA. Documentos, 29).

WANG, J.; SUN, B.; CAO, Y.; TIAN, Y.; WANG, C. Enzymatic preparation of wheat bran xylooligosaccharides and their stability during pasteurization and autoclave sterilization at low pH. Carbohydrate Polymers, v.77, p.816-821, 2009. DOI: https://doi.org/10.1016/j.carbpol.2009.03.005.

YUYAMA, L.K.O.; PANTOJA, L.; MAEDA, R.N.; AGUIAR, J.P.L.; SILVA, S.B. da. Desenvolvimento e aceitabilidade de geléia dietética de cubiu (Solanum sessiliflorum Dunal). Ciência e Tecnologia de Alimentos, v.28, p.929-934, 2008. DOI: https://doi.org/10.1590/s0101-20612008000400026. 